\title{
Article
}

\section{TaGRF3-2A Improves Some Agronomically Valuable Traits in Semi-Dwarf Spring Triticale}

\author{
Mikhail Divashuk ${ }^{1,2, *(\mathbb{D})}$, Anastasiya Chernook ${ }^{1} \mathbb{1}$, Aleksandra Kroupina ${ }^{1}$, Milena Vukovic ${ }^{1}$, \\ Gennady Karlov ${ }^{1}{ }^{\infty}$, Aleksey Ermolaev ${ }^{1}{ }^{(0}$, Sergey Shirnin ${ }^{1}$, Sergey Avdeev ${ }^{2}$, Vladimir Igonin ${ }^{1,2}$, \\ Vladimir Pylnev ${ }^{2}$ and Pavel Kroupin ${ }^{1}$ \\ 1 All-Russia Research Institute of Agricultural Biotechnology, Timiryazevskaya Street, 42, \\ 127550 Moscow, Russia; irbis-sibri@yandex.ru (A.C.); annshirley@yandex.ru (A.K.); \\ milenna.vukovic@gmail.com (M.V.); karlov@iab.ac.ru (G.K.); ermol-2012@yandex.ru (A.E.); \\ durandal-1707@bk.ru (S.S.); selection@timacad.ru (V.I.); pavelkroupin1985@gmail.com (P.K.) \\ 2 Institute of Agrobiotechnology, Russian State Agrarian University-Moscow Timiryazev Agricultural \\ Academy, Timiryazevskaya Street, 49, 127550 Moscow, Russia; avdeev@rgau-msha.ru (S.A.); \\ pyl8@yandex.ru (V.P.) \\ * Correspondence: divashuk@gmail.com; Tel.: +7-499-977-72-01
}

check for updates

Citation: Divashuk, M.; Chernook,

A.; Kroupina, A.; Vukovic, M.; Karlov,

G.; Ermolaev, A.; Shirnin, S.; Avdeev,

S.; Igonin, V.; Pylnev, V.; et al.

TaGRF3-2A Improves Some

Agronomically Valuable Traits in

Semi-Dwarf Spring Triticale. Plants

2021, 10, 2012. https://

doi.org/10.3390/plants10102012

Academic Editor: Ana Butrón

Received: 8 September 2021

Accepted: 23 September 2021

Published: 25 September 2021

Publisher's Note: MDPI stays neutral with regard to jurisdictional claims in published maps and institutional affiliations.

Copyright: (C) 2021 by the authors. Licensee MDPI, Basel, Switzerland. This article is an open access article distributed under the terms and conditions of the Creative Commons Attribution (CC BY) license (https:// creativecommons.org/licenses/by/ $4.0 /)$.

\begin{abstract}
The breeding improvement of triticale is tightly associated with the introgression of dwarfing genes, in particular, gibberellin (GA)-insensitive Ddw1 from rye. Despite the increase in harvest index and resistance to lodging, this gene adversely affects grain weight and size. Growth regulation factor $(G R F)$ genes are plant-specific transcription factors that play an important role in plant growth, including GA-induced stem elongation. This study presents the results of a two-year field experiment to assess the effect of alleles of the TaGRF3-2A gene in interaction with DDW1 on economically valuable traits of spring triticale plants grown in the Non-Chernozem zone. Our results show that, depending on the allelic state, the TaGRF3-2A gene in semi-dwarf spring triticale plants influences the thousand grain weight and the grain weight of the main spike in spring triticale, which makes it possible to use it to compensate for the negative effects of the dwarfing allele Ddw1. The identified allelic variants of the TaGRF3-2A gene can be included in marker-assisted breeding for triticale to improve traits.
\end{abstract}

Keywords: triticale; TaGRF3-2A; DDW1; yield; molecular marker

\section{Introduction}

Triticale is an important food crop that combines the genomes of wheat and rye. Due to its high ecological plasticity and adaptability, triticale is successfully grown in poor soils and is resistant to a wide range of fungal diseases [1-8]. Triticale is grown as a forage crop for grain and green mass. Recently, triticale grain has also been used for the production of biogas and bioethanol, and it may also have prospects in the production of functional foods [9-11].

Triticale breeding has made significant progress; thanks to breeding, it was possible to improve its feeding qualities and remove such undesirable traits as preharvest sprouting and lodging. As a result of lodging, the straw cannot withstand a heavy ear and bends towards the ground. Lodging reduces the efficiency of photosynthesis due to changes in the architecture of the stem, leads to seed germination and phytotoxin contamination, slows down maturation, and requires additional costs for drying [12,13].

The development of semi-dwarf varieties is a reliable way to solve the lodging problem. Dwarfing genes reduce the height of the straw, increasing the yield via higher grain number per ear yield without the risk of losing it as a result of lodging [14,15]. However, in experiments with isogenic recombinant lines, the dwarfing genes, as a rule, reduce the thousand grain weight, impair the assimilation of soil nitrate nitrogen, and reduce drought resistance, and they can extend the periods of flowering and heading $[16,17]$. 
Growth regulation factor (Grf) genes are plant-specific transcription factors that play an important role in plant growth, including gibberellin (GA)-induced stem elongation [18] In rice, a mechanism for the regulation of the activity of DELLA protein, which inhibits nitrogen assimilation and carbon fixation, by means of OsGRF4 was revealed: in dwarf rice plants and transgenic wheat plants with the GRF4 ${ }^{\text {ngr2 }}$ allele, the activities of glutamate synthase and nitrate reductase were higher than those in control plants. As a result of the expression of this allele, a larger grain was formed while maintaining the semi-dwarf phenotype $[19,20]$. In common wheat, $30 \mathrm{TaGRF}$ genes were identified on 12 chromosomes, which were divided into four phylogenetic groups [21,22]. Analysis of the TaGRF3 gene sequence on the 2D common wheat chromosome using molecular markers showed its allelic diversity among the accessions of the collection, as well as a correlation with thousand grain weight and the size of wheat kernels [23]. A number of authors propose that it is the tuning of genes of nitrogen metabolism in low-stemmed varieties that will drive a new wave of the green revolution, increasing the absorption of nitrogen and, as a consequence, the weight of the grain $[19,24,25]$.

The triticale genome makes it possible to successfully combine genes for dwarfism from both wheat and rye. Among the dwarfing genes of rye, the dominant allele Ddw 1 has the greatest agricultural value. The Gibberellin 2-Oxidase gene is considered a candidate for Ddw1, while its ortholog in wheat is considered to be the Rht12 gene [14,26-30]. It is able to reduce the height of plants by $25-30 \%$, but at the same time, it reduces the thousand grain weight and the weight of grains per ear [31-37]. Ddw1 is successfully used in triticale breeding in Poland, Romania, and other European countries $[14,38,39]$. In our work, we carried out a two-year study on the interaction of the TaGRF3-2A (hereafter designated in the test as Grf3) and Ddw1 genes in spring triticale in the field conditions of the Central Non-Chernozem (Non-Black Earth) Region of the Russian Federation.

\section{Results}

The field experiments in 2018 and 2019 differed in terms of meteorological conditions (Table 1). In general, 2019 was more favorable for the formation of the spring triticale yield for all families and any combination of genes. The yield elements formed in 2019, on average, were higher than those in 2018: the vegetative mass of the main spike in 2019 exceeded that in 2018 by $17 \%$ ( $0.5 \mathrm{~g})$, the grain weight of the main spike was increased by $18 \%(0.4 \mathrm{~g})$, the thousand grain weight was increased by $22 \%(11.3 \mathrm{~g})$, the number of fertile tillers was on average $33 \%$ higher (one shoot), and the harvesting index was $8 \%$ higher. In addition, in 2018, only $23.5 \%$ of plants had six internodes; in 2019, $41.3 \%$ of plants had six internodes.

Table 1. Agroclimatic conditions of field experiments in 2018-2019.

\begin{tabular}{ccccc}
\hline \multirow{2}{*}{ Month } & \multicolumn{2}{c}{ Sum of Precipitation $(\mathbf{m m})$} & \multicolumn{2}{c}{ Average Temperature $\left({ }^{\circ} \mathbf{C}\right)$} \\
\cline { 2 - 5 } & $\mathbf{2 0 1 8}$ & $\mathbf{2 0 1 9}$ & $\mathbf{2 0 1 8}$ & $\mathbf{2 0 1 9}$ \\
\hline May & 44 & 58 & 16.1 & 16.2 \\
\hline June & 54 & 55 & 17.2 & 19.6 \\
\hline July & 85 & 64 & 20.3 & 16.7 \\
\hline August & 20 & 48 & 19.8 & 16.4 \\
\hline
\end{tabular}

The effect of $D d w 1$ on economically valuable traits of spring triticale in our experiments generally showed trends the same as those in studies by other authors and in our previous studies [31-35,40]. On average, for both years of the experiment, Ddw1 reduced the height of spring triticale plants by $33 \%(28.2 \mathrm{~cm})$. The vegetative mass of the main spike and the grain weight of the main spike, on average, in semi-dwarf plants (Ddw1Ddw1) were lower than those in tall plants $(d d w 1 d d w 1)$ by $10 \%(0.3 \mathrm{~g})$ and $9 \%(0.2 \mathrm{~g})$, respectively. The thousand grain weight in semi-dwarf plants was, on average, $6 \%$ lower, and the presence of $D d w 1$, on average, increased the harvesting index by $8 \%$ ( 0.05 units). Plants of spring 
triticale with $D d w 1$, on average, came to heading and anthesis 5 days later than did tall triticale plants.

\subsection{Spike Architecture and Productivity}

We revealed a statistically significant effect of allelic variants of the TaGRF3-2A (hereafter designated in the test as Grf3) gene upon interaction with the $D d w 1$ gene on the grain weight of the main spike in both generations.

The grain weight of the main spike in $\mathrm{F}_{4: 5}$ (2018) in semi-dwarf $D d w 1$-carrying plants with the Grf3(274) allele was 35\% (0.7 g) higher than that in such plants with the Grf3(262) allele. In $\mathrm{F}_{5: 6}$ (2019), the $\mathrm{Grf3}(274)$ allele increased the grain weight from the main spike by $12 \%(0.3 \mathrm{~g})$ (Table S1) (Figure 1$)$. In tall plants of spring triticale (without Ddw1) in $\mathrm{F}_{4: 5}$ (2018) and $\mathrm{F}_{5: 6}(2019)$, no statistically significant difference was observed in the grain weight per spike between different Grf3 genotypes.

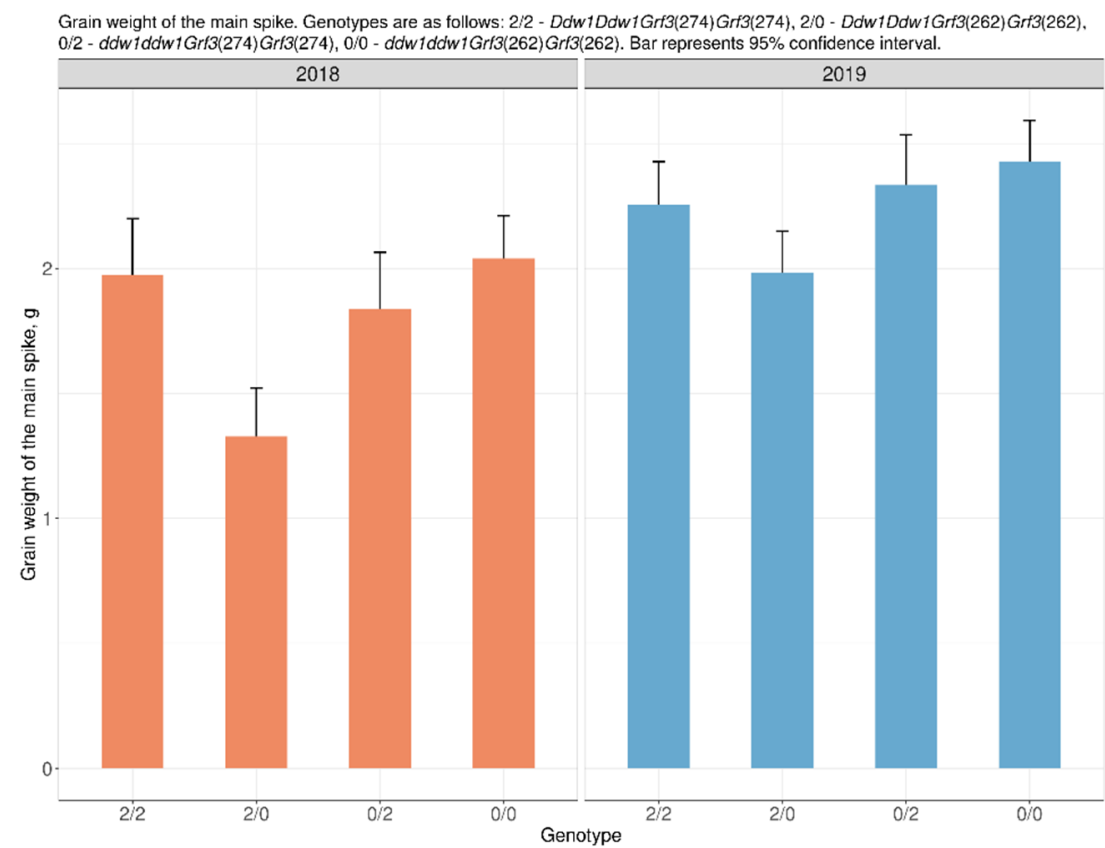

Figure 1. The effect of the allelic state of DDW1 and Grf3 on grain weight of the main spike.

The thousand grain weight in spring triticale plants with the dwarfing Ddw1 and Grf3(274) alleles was statistically significantly higher by $5.94 \mathrm{~g}(16 \%)$ compared to that in semi-dwarf plants with the Ddw1/Grf3(262) combination in $\mathrm{F}_{4: 5}$ (2018). In $\mathrm{F}_{5: 6}$ (2019), the difference between the same combinations of alleles was $2.96 \mathrm{~g}(6 \%)$, but no statistical significance was found. In tall plants of spring triticale (without $D d w 1$ ) in $\mathrm{F}_{4: 5}(2018)$ and $\mathrm{F}_{5: 6}$ (2019), no statistically significant difference in thousand grain weight between different allelic variants of the Grf3 gene was found. The number of grains per main spike did not show statistically significant differences between the combinations of genes in both years of the study, although certain trends were observed (Table S1, Figure 2). 


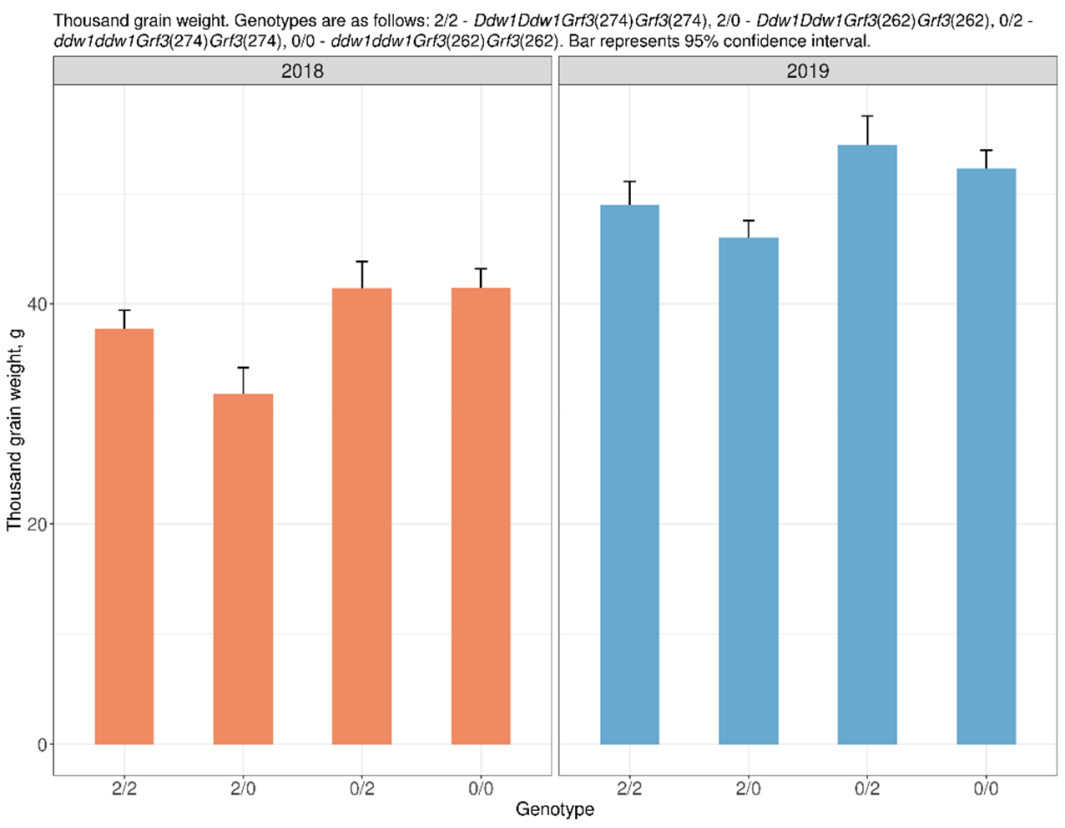

Figure 2. The effect of the allelic state of DDW1 and Grf3 on thousand grain weight.

\subsection{Flowering and Heading}

We obtained a rather unexpected effect when assessing the effect of the combination of the studied genes on flowering and heading. As expected, the presence of Ddw1 resulted in later flowering: semi-dwarf plants bloomed, on average, 5 days later than tall plants. However, when taking into account the allelic state of the Grf3 gene, it was found that in $\mathrm{F}_{5: 6}$ (2019) in semi-dwarf plants with the Grf3(274) allele, heading and anthesis occurred, on average, 7 days earlier than in plants with the Grf3(262). In $\mathrm{F}_{4: 5}$ (2018), the difference was 5-6 days, but due to unfavorable conditions in 2018, the transition between the phases was significantly extended in time, which did not result in statistically significant differences. In tall plants, the Grf3 gene had no effect on the heading and anthesis time (Table S1, Figure 3).

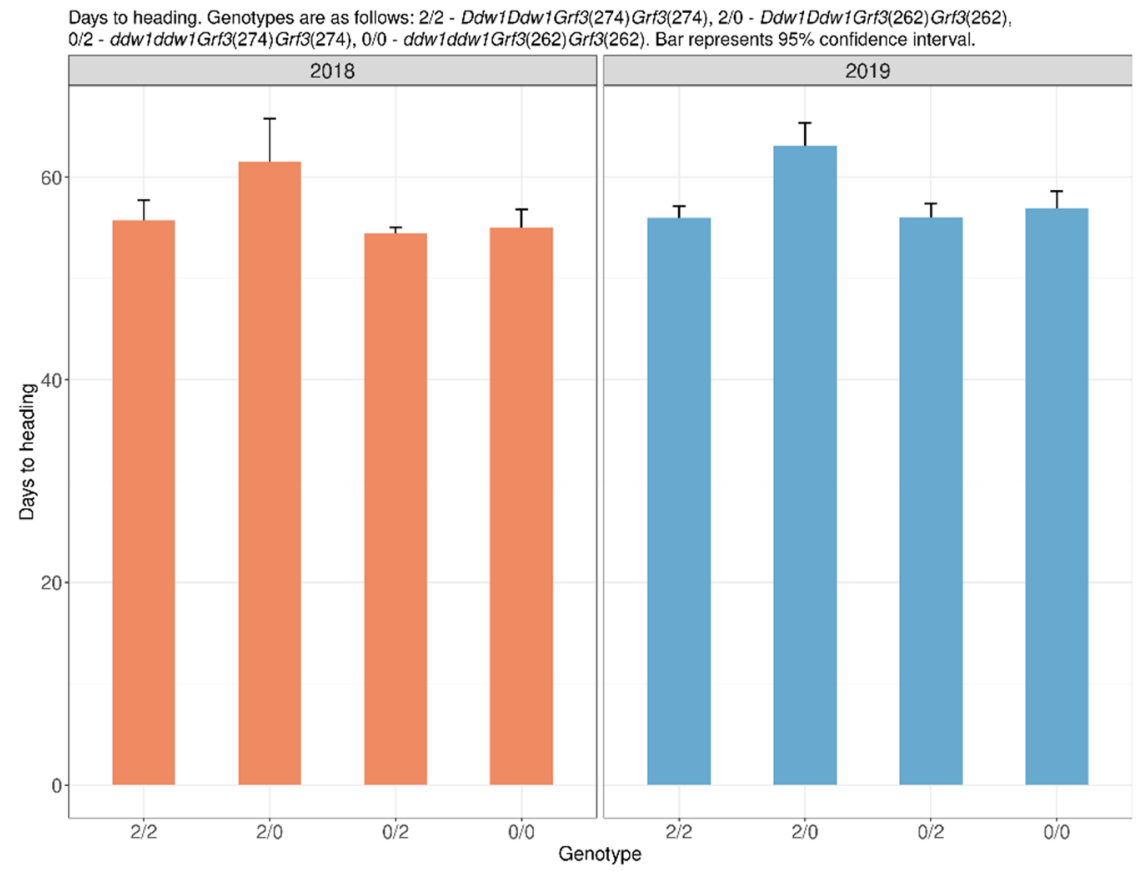

Figure 3. The effect of the allelic state of DDW1 and Grf3 on period duration from sowing to heading. 


\subsection{Plant Height, Internodes, and Main Spike Length}

An analysis of the effect of $D d w 1$ on the anatomical structure of the stem in the field experiment showed the expected results of a significant decrease in plant height (Table S1, Figure 4).

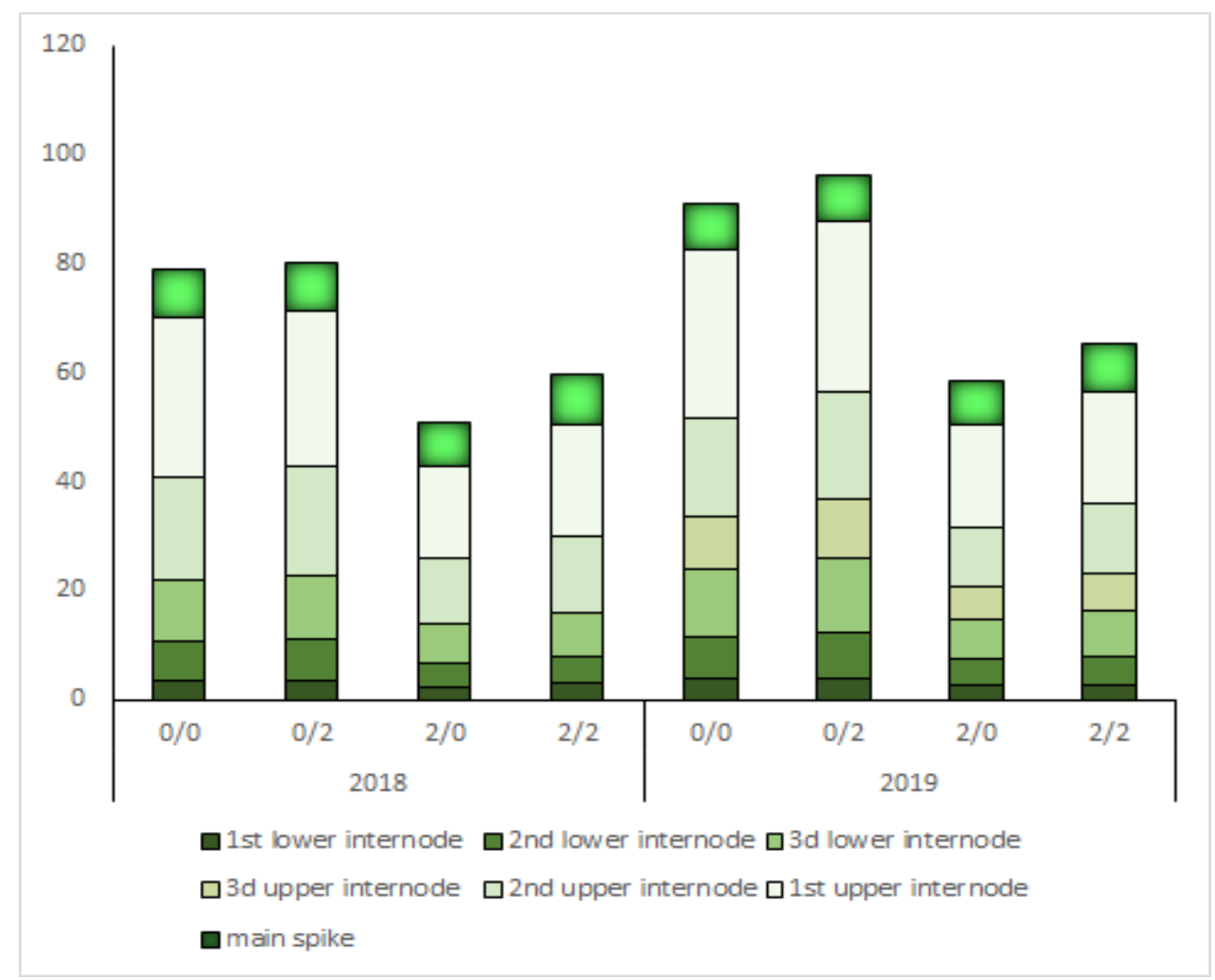

Figure 4. Schematic diagram showing the internode and spike length of the main shoot of spring triticale plants with different combinations of the DDW1 and Grf3 alleles. Genotypes are as follows: 2/2 Ddw1Ddw1Grf3(274)Grf3(274), 2/0 Ddw1Ddw1Grf3(262)Grf3(262), 0/2 ddw1ddw1Grf3(274)Grf3(274), $0 / 0$ ddw1ddw1Grf3(262)Grf3(262).

The allelic state Grf3 had little effect on plant height. Allele Grf3(274) insignificantly increased plant height in all combinations by from 1 to $6 \mathrm{~cm}$. However, this was more obvious in semi-dwarf plants. The plants with the Grf3(274) allele were $6 \mathrm{~cm}$ taller than those with the Grf3(262) allele.

\section{Discussion}

Experimental conditions in the Non-Black Earth Zone in 2018 and 2019 differed both in meteorological conditions and in average plant productivity. Thus, in the present study, we compared two different years, which allowed us to compare the manifestation of TaGRF3$2 A$ (designated here as Grf3) under different conditions in low-stem and high-stem plants of spring triticale.

In the present study, we showed that the allelic state of TaGRF3-2A in semi-dwarf plants carrying Ddw1 affects plant productivity, thousand grain weight, and grain weight from the main spike, demonstrating a partial compensatory effect on these traits in comparison with the negative effect of the $D d w 1$ gene. At the same time, it can be noted that the effect manifested more significantly under 2018 conditions, which were unfavorable for spring triticale. In our previous study [34], we showed the effect of TaGRF3-2D on the weight and dimensions of the seed in a bread wheat collection. Zan et al. (2020) showed that the TaGRF3 gene (as well as its B- and D-genome homologues TaGRF-15 and TaGRF-23) has an increased level of expression in the ear [41]. 
The effect of $D d w 1$ on the linear parameters of the stem under the influence in both years of the field experience was quite similar: the overall decrease was $33 \%$, which is generally consistent with previous studies [31-35]. On the whole, TaGRF3-2A did not have a significant effect on the height of triticale plants; however, the allele state Grf3(274) increased the length of individual internodes and the length of the spike. Expression data from Zan (2020) and Huang (2021) showed that TaGRF3-2A (Grf3) has higher expression in the stem and apical meristem. Thus, the presence of the TaGRF3-2A (274) allele in semi-dwarf plants leads to only a slight increase in plant height (up to $6 \mathrm{~cm}$ ) and, therefore, does not interfere with the semi-dwarf phenotype of the variety required for intensive cultivation technology and control of lodging [22,41].

It is known that both genes studied by us are involved in gibberellin pathways and thus affect the linear dimensions of the stem, ear, and grain. The gibberellin-sensitive $D d w 1$ gene was shown to co-segregate with the ScGA2ox12 gibberellin-2 oxidase gene [30], while its most likely wheat homolog, the Rht12 gene, probably decreases plant height through its influence on the TaGA2ox-A14 gibberellin metabolism gene [42,43]. Rice OsGRF genes, through participation in gibberellin pathways and in interaction with miR396, affect stem length [18], grain size [20], and plant architecture as a whole [44]. Thus, we can assume the interaction of TaGRF3-2A and DELLA proteins in the formation of the stem and spike such as at the stage of the apical meristem, the initiation of generative organs in the spike, stem growth, and grain filling by means of gibberellin pathways.

It is known that gibberellin-sensitive dwarfing genes significantly extend the periods of heading and anthesis in cereals. This has been demonstrated for the Ddw1 genes in triticale $[32-35,45,46]$, which negatively correlate with Fusarium spike resistance. A similar effect was also noted in its most likely homologue, the Rht12 gene in wheat [47-49]. The later the flowering, the shorter the favorable period for grain filling [50]. We showed that due to the presence of TaGRF3-2A (274) in semi-dwarf plants, flowering and heading occur earlier, which increases the period for grain formation. As a discussion, we can assume the hormonal influence of the TaGRF3-2A (274) allele on the rate of cell division/elongation in grain, since we have shown its positive effect on an increase in the linear dimensions of the ear and stem. However, the study of the influence of the TaGRF3-2A gene requires further field studies in different crops and molecular genetic studies to study its mechanism of action.

\section{Materials and Methods}

\subsection{Plant Material}

As a parental form, triticale cultivars bearing contrasting combinations of DDW1 and Grf3 alleles were chosen. Tall spring triticale cv. 'Dublet' with genotype ddw1ddw1 Grf3(274)Grf3(274) (Danko Hodowla Ro'slin Sp. z o.o., Poland) was used as the paternal form, and semi-dwarf winter triticale cv. 'Hongor' with genotype Ddw1Ddw1 Grf3(262)Grf3(262) (Lukyanenko National Grain Centre, Russia) was used as the maternal form. The hybrid $F_{1}$ plants were grown in vegetation pots in 2016 in a greenhouse at the Center of Molecular Biotechnology. The $\mathrm{F}_{2}$ seeds were planted in vegetation pots at 10 seeds per pot. The $\mathrm{F}_{2: 3}$ seeds of the spike of each of the $\mathrm{F} 2$ plants were manually threshed and combined into a single family. The homozygous $F_{2: 3}$ plants with Ddw1 and ddw1 alleles were selected by genotyping and grown to produce the $F_{3: 4}$ plants. The $F_{5}$ and $F_{6}$ seeds of the spike of each plant were obtained by mechanical threshing of $F_{4: 5}$ and $F_{5: 6}$ combining typical plants, respectively [35]. Each generation was additionally genotyped using molecular markers.

\subsection{Field Experiment}

A field experiment with plants was carried out in Moscow at the Field Experimental Station of the RSAU-Moscow Timiryazev Agricultural Academy $\left(55^{\circ} 50^{\prime} \mathrm{N}, 37^{\circ} 33^{\prime} \mathrm{E}\right.$ ) in 2018-2019. Moscow (Central Non-Black Earth Region, moderate continental climate) is distinguished by a large amount of precipitation, moderate temperatures, and sod-podzolic 
soils. Sowing was performed in Moscow on May 5 in 2018 and on April 23 in 2019. Sowing in both years was carried out by the cassette method using an SKS-6-10 breeding seeder with the following parameters: plot length $1 \mathrm{~m}$, in 4 rows with a row spacing of $30 \mathrm{~cm}$ and a distance between plots of $50 \mathrm{~cm}$. Weeds were pulled out by hand, and the necessary treatment with pesticides was carried out to protect the plants from pests. Each plant was manually harvested upon reaching the full ripeness phase; the final harvest days were on 19 August 2018 and 23 August 2019 (Table 1).

In the present study, we used data from the analysis of $\mathrm{F}_{4: 5}$ plant material obtained in 2018 (published in Kroupin et al. 2019) and newly obtained $F_{5: 6}$ plant material grown in 2019 [34]. The $\mathrm{F}_{5}$ and $\mathrm{F}_{6}$ seeds of the spike of each plant were obtained by mechanical threshing of $\mathrm{F}_{4: 5}$ and $\mathrm{F}_{5: 6}$ plants, respectively. The plants of $\mathrm{F}_{4: 5}$ were grown and harvested in 2018 and mechanically threshed using an MKS-1M spike thresher (MZOK Company, Moscow, Russia). $F_{5}$ seeds from each plant were combined into a single family (recombinant inbred line) and were used to grow $\mathrm{F}_{5: 6}$ plants in 2019. The allelic states of DDW1 and Grf3 were determined in parental $\mathrm{F}_{4: 5}$ (using stored DNA) and $\mathrm{F}_{5: 6}$ plants such that the seeds from homozygous plants were selected for growing and subsequent analysis.

The weather conditions in 2018 and 2019 are displayed in Table 1. The numbers of plant samples in the analyzed families are shown in Table 2.

Table 2. Numbers of analyzed $\mathrm{F}_{4: 5}(2018)$ and $\mathrm{F}_{5: 6}(2019)$ plant samples by genotype.

\begin{tabular}{ccc}
\hline Genotype & $\mathbf{F}_{4: 5} \mathbf{( 2 0 1 8 )}$ & $\mathbf{F}_{5: 6}(\mathbf{2 0 1 9 )}$ \\
\hline$D d w 1 D d w 1 G r f 3(274) G r f 3(274)$ & 45 & 268 \\
\hline$d d w 1 d d w 1 G r f 3(274) G r f 3(274)$ & 216 & 304 \\
\hline$d d w 1 d d w 1 G r f 3(262) G r f 3(262)$ & 351 & 472 \\
\hline$D d w 1 D d w 1 G r f 3(262) G r f 3(262)$ & 106 & 262 \\
\hline
\end{tabular}

Analyzing the data presented in Table 1, it can be noted that in 2018, at the end of the growing season, unfavorable conditions occurred in the form of an extremely small amount of precipitation in August (25.6\% of the norm), while 2019 had more even meteorological values, according to which the current climatic norm was approached.

\subsection{Plant Structural Analysis}

The following phenotype features of each plant were recorded (all spike parameters were measured in the main spike): plant height ( $\mathrm{PH}$, centimeters), spike length (SL, centimeters), spikelet number per spike (SNS), spike density (SD, calculated as tenfold SNS divided by SL), grain weight per spike (GWS, grams), grain number per spike (GNS), grain weight per spikelet (GNSpl, grams), thousand grain weight (TGW, calculated as thousandfold GWS divided by GNS, grams), number of fertile tillers (NFT), number of internodes (NI), heading date (HD, days after sowing), flowering date (FD, days after sowing), harvest index (HI), peduncle length (first internode below the spike, centimeters), second upper internode length (centimeters), third upper internode length (centimeters), fourth upper internode length (where present, centimeters), second lower internode length, and first lower internode (the lowest) length (centimeters). The harvest index was calculated as the ratio of the grain weight from the main spike to the total weight of the unthreshed spike and the peduncle. Flowering and heading phases were determined visually for the whole family. The seeds were counted by the SeedCounter application [51]. A total of 1293 spring triticale plants were analyzed in 2018, and 1193 were analyzed in 2019.

\subsection{Plant Genotyping}

During the tilling phase, a leaf fragment of approximately $2 \mathrm{~cm}$ long was sampled from each plant, and DNA was isolated by the CTAB method for verification of the DDW1 and Grf3 hybrid genotype. DNA was extracted from no fewer than two labeled plants 
per family to determine the allelic states of DDW1 and Grf3. The primers targeted the microsatellite locus REMS1218, which is tightly linked to DDW1. The alleles of the REMS1218 microsatellites were assayed by PCR with subsequent fragment analysis performed using a Nanophor05 (Syntol, Russia Federation, Moscow) (Figure 5). Additionally, we used CAPS marker for the detection of the dwarfing Ddw1 allele [52]. To detect polymorphism in the microsatellite locus of the $5^{\prime}$-untranslated region in Grf3, we designed primers F: 5'-GTAGGAGTAAAAGGCAAAAGCACG-3' and R: 5'-ACAGGGAGGCAAAGGGCATC3' (Figure 6) [23,31]. The alleles of Grf3 were assayed by PCR with subsequent fragment analysis performed using a 3130xl Genetic Analyzer (Applied Biosystems, Foster City, CA, USA).

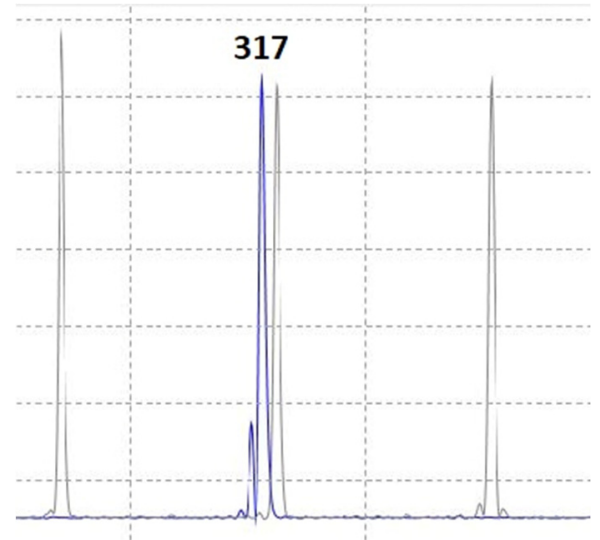

(a)

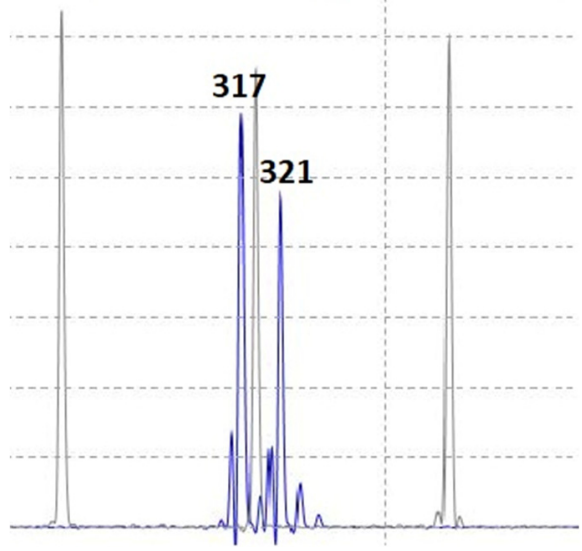

(b)

Figure 5. Identification of the allelic state of DDW1 using fragment analysis of the REMS1218 marker amplicons: tall $d d w 1$ allele (a) and dwarfing $D d w 1$ allele (b).
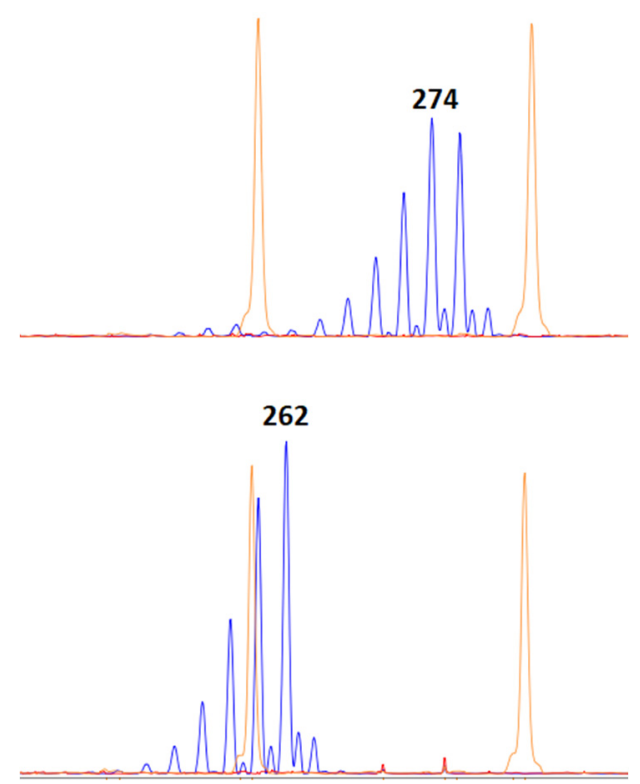

Figure 6. Identification of the allelic state of Grf3 in parental spring triticale cultivars using fragment analysis: Grf3(274) in Dublet and Grf3(262) in Hongor.

\subsection{Statistical Analysis}

Data analysis was performed using R v3.6.3. An analysis of variation (ANOVA) between the allelic state of Ddw1 and Grf3 genes and phenotype was carried out using the Anova function from the "car" package [53] on a significance level of $p<0.05$. For pair-wise comparisons, Tukey's test was used. Plots were created using the "ggplot2" package [54]. 


\section{Conclusions}

In our study, we demonstrated a partial compensatory positive effect of the TaGRF3-2A gene on important yield components, such as grain weight of the main spike, thousand grain weight, and heading and anthesis time, in the presence of the dwarfing Ddw1 allele. The $D d w 1$ allele is necessary in modern triticale breeding, but it has a sharply negative effect on these traits. Based on this and our previous work, we propose an effective molecular marker for the allelic state of the TaGRF3-2A gene. This allows the TaGRF3-2A gene to be quickly incorporated into the breeding process to compensate for the negative effects of gibberellin-sensitive dwarfing genes.

Supplementary Materials: The following are available online at https:/ /www.mdpi.com/article/10 .3390/plants10102012/s1, Table S1: Effects of TaGRF3-2A and Ddw1 in the spring triticale 'Hongor' $\times$ 'Dublet' population $\mathrm{F}_{4: 5}$ and $\mathrm{F}_{5: 6}$ in the field experiments.

Author Contributions: Conceptualization, M.D. and G.K.; methodology, M.D., V.P. and G.K.; validation, A.K., M.V. and A.C.; formal analysis, A.K., M.V., S.S., S.A., A.E. and A.C.; investigation, A.K., M.V., V.I. and A.C.; resources, M.D.; data curation, M.D. and P.K.; writing-original draft preparation, P.K. and A.C.; writing—review and editing, P.K., M.D., G.K. and A.C.; supervision, M.D.; project administration, M.D.; funding acquisition, M.D. and A.C. All authors have read and agreed to the published version of the manuscript.

Funding: The reported study was funded by RFBR, project number 20-316-90046.

Institutional Review Board Statement: Not applicable.

Informed Consent Statement: Not applicable.

Conflicts of Interest: The authors declare no conflict of interest.

\section{References}

1. Sherman, J.F.; Young, E.O.; Cavadini, J. Tillage and Liquid Dairy Manure Effects on Overland Flow Nitrogen and Phosphorus Loss Potential in an Upper Midwest Corn Silage-Winter Triticale Cropping System. Agronomy 2021, 11, 1775. [CrossRef]

2. Bartosiak, S.F.; Arseniuk, E.; Szechyńska-Hebda, M.; Bartosiak, E. Monitoring of Natural Occurrence and Severity of Leaf and Glume Blotch Diseases of Winter Wheat and Winter Triticale Incited by Necrotrophic Fungi Parastagonospora spp. and Zymoseptoria tritici. Agronomy 2021, 11, 967. [CrossRef]

3. Góral, T.; Wiśniewska, H.; Ochodzki, P.; Twardawska, A.; Walentyn-Góral, D. Resistance to Fusarium Head Blight, Kernel Damage, and Concentration of Fusarium Mycotoxins in Grain of Winter Triticale (x Triticosecale Wittmack) Lines. Agronomy 2021, 11, 16. [CrossRef]

4. Schillinger, W.F.; Archer, D.W. Winter Triticale: A Long-Term Cropping Systems Experiment in a Dry Mediterranean Climate. Agronomy 2020, 10, 1777. [CrossRef]

5. Yerzhebayeva, R.S.; Bazylova, T.A.; Babissekova, D.I.; Amangeldiyeva, A.A.; Tajibayev, D.G.; Ydyrys, A. Studying a Spring Triticale Collection for Resistance to Leaf and Stem Rusts using Allele-Specific Markers. Cytol. Genet. 2020, 54, 546-554. [CrossRef]

6. Skowrońska, R.; Tomkowiak, A.; Nawracała, J.; Kwiatek, M. Molecular identification of slow rusting resistance Lr46/Yr29 gene locus in selected triticale ( $\times$ Triticosecale Wittmack) cultivars. J. Appl. Genet. 2020, 61, 359-366. [CrossRef]

7. Rajičić, V.; Popović, V.; Perišić, V.; Biberdžić, M.; Jovović, Z.; Gudžić, N.; Mihailović, V.; Čolić, V.; Đurić, N.; Terzić, D. Impact of Nitrogen and Phosphorus on Grain Yield in Winter Triticale Grown on Degraded Vertisol. Agronomy 2020, 10, 757. [CrossRef]

8. Bielski, S.; Romaneckas, K.; Šarauskis, E. Impact of Nitrogen and Boron Fertilization on Winter Triticale Productivity Parameters. Agronomy 2020, 10, 279. [CrossRef]

9. Wójcik-Gront, E.; Studnicki, M. Long-Term Yield Variability of Triticale ( $\times$ Triticosecale Wittmack) Tested Using a CART Model. Agriculture 2021, 11, 92. [CrossRef]

10. Klikocka, H.; Kasztelan, A.; Zakrzewska, A.; Wyłupek, T.; Szostak, B.; Skwaryło-Bednarz, B. The Energy Efficiency of the Production and Conversion of Spring Triticale Grain into Bioethanol. Agronomy 2019, 9, 423. [CrossRef]

11. Sestili, F.; Margiotta, B.; Vaccino, P.; Moscaritolo, S.; Giorgi, D.; Lucretti, S.; Palombieri, S.; Masci, S.; Lafiandra, D. A Cross between Bread Wheat and a 2D(2R) Disomic Substitution Triticale Line Leads to the Formation of a Novel Disomic Addition Line and Provides Information of the Role of Rye Secalins on Breadmaking Characteristics. Int. J. Mol. Sci. 2020, 21, 8450. [CrossRef]

12. Dreccer, M.F.; Condon, A.G.; Macdonald, B.; Rebetzke, G.J.; Awasi, M.-A.; Borgognone, M.G.; Peake, A.; Piñera-Chavez, F.J; Hundt, A.; Jackway, P.; et al. Genotypic variation for lodging tolerance in spring wheat: Wider and deeper root plates, a feature of low lodging, high yielding germplasmmm. Field Crop Res. 2020, 258, 107942. [CrossRef] 
13. Hura, T.; Dziurka, M.; Hura, K.; Ostrowska, A.; Dziurka, K.; Gadzinowska, J. Wheat and rye genome confer specific phytohormone profile features and interplay under water stress in two phenotypes of triticale. Plant Physiol. Biochem. 2017, 118, 494-509. [CrossRef]

14. Trini, J.; Maurer, H.P.; Neuweiler, J.E.; Würschum, T. Identification and Fine-Mapping of Quantitative Trait Loci Controlling Plant Height in Central European Winter Triticale ( $\times$ Triticosecale Wittmack). Plants 2021, 10, 1592. [CrossRef] [PubMed]

15. Jatayev, S.; Sukhikh, I.; Vavilova, V.; Smolenskaya, S.E.; Goncharov, N.P.; Kurishbayev, A.; Zotova, L.; Absattarova, A.; Serikbay, D.; Hu, Y.; et al. Green revolution 'stumbles' in a dry environment: Dwarf wheat with Rht genes fails to produce higher grain yield than taller plants under drought. Plant Cell Environ. 2020, 43, 2355-2364. [CrossRef] [PubMed]

16. Sukhikh, I.; Vavilova, V.; Blinov, A.; Goncharov, N. Diversity and Phenotypical Effect of the Allele Variants of Dwarfing Rht Genes in Wheat. Russ J. Genet. 2021, 57, 127-138. [CrossRef]

17. Dowla, M.; Islam, S.; Stefanova, K.; Hara, G.O.; Ma, W.; Edwards, I. Phenology and Dwarfing Gene Interaction Effects on the Adaptation of Selected Wheat (Triticum aestivum L.) Advanced Lines across Diverse Water-Limited Environments of Western Australia. Agriculture 2020, 10, 470. [CrossRef]

18. van der Knaap, E.; Kim, J.H.; Kende, H. A novel gibberellin-induced gene from rice and its potential regulatory role in stem growth. Plant Physiol. 2000, 122, 695-704. [CrossRef]

19. Li, S.; Tian, Y.; Wu, K.; Ye, Y.; Yu, J.; Zhang, J.; Liu, Q.; Hu, M.; Li, H.; Tong, Y.; et al. Modulating plant growth-metabolism coordination for sustainable agriculture. Nature 2018, 560, 595-600. [CrossRef]

20. Che, R.; Tong, H.; Shi, B.; Liu, Y.; Fang, S.; Liu, D.; Xiao, Y.; Hu, B.; Liu, L.; Wang, H.; et al. Control of grain size and rice yield by GL2-mediated brassinosteroid responses. Nat. Plants 2016, 2, 15195. [CrossRef]

21. Zhang, J.; Zhou, Z.; Bai, J.; Tao, X.; Wang, L.; Zhang, H.; Zhu, J.K. Disruption of MIR396e and MIR396f improves rice yield under nitrogen-deficient conditions. Natl. Sci. Rev. 2020, 7, 102-112. [CrossRef]

22. Huang, W.; He, Y.; Yang, L.; Lu, C.; Zhu, Y.; Sun, C.; Ma, D.; Yin, J. Genome-wide analysis of growth-regulating factors (GRFs) in Triticum aestivum. Peer] 2021, 9, e10701. [CrossRef] [PubMed]

23. Kroupin, P.Y.; Chernook, A.; Bazhenov, M.; Karlov, G.I.; Goncharov, N.P.; Chikida, N.N.; Divashuk, M.G. Allele mining of TaGRF-2D gene 5'-UTR in Triticum aestivum and Aegilops tauschii genotypes. PLoS ONE 2020, 15, e0231704. [CrossRef] [PubMed]

24. Ma, K.; Liu, Y.G. DELLA-GRF4-mediated coordination of growth and nitrogen metabolism paves the way for a new Green Revolution. Sci. China Life Sci. 2018, 61, 1130-1131. [CrossRef]

25. Xue, H.; Zhang, Y.; Xiao, G. Neo-gibberellin signaling: Guiding the next generation of the green revolution. Trends Plant Sci. 2020, 25, 520-522. [CrossRef] [PubMed]

26. Ben Amer, I.M.; Korzun, V.; Worland, A.J.; Börner, A. Genetic mapping of QTL controlling tissue culture response on chromosome 2B of wheat (Triticum aestivum L.) in relation to major genes and RFLP markers. Theor. Appl. Genet. 1997, 94, 1047-1052. [CrossRef]

27. Börner, A.; Röder, M.; Korzun, V. Comparative molecular mapping of GA insensitive Rht loci on chromosomes 4B and 4D of wheat (Triticum aestivum L.). Theor. Appl. Genet. 1997, 95, 1133-1137. [CrossRef]

28. Korzun, V.; Börner, A.; Worland, A.J.; Law, C.N.; Röder, M.S. Application of microsatellite markers to distinguish inter-varietal chromosome substitution lines of wheat (Triticum aestivum L.). Euphytica 1997, 95, 149-155. [CrossRef]

29. Korzun, V.; Röder, M.; Worland, A.J.; Börner, A. Intrachromosomal mapping of the dwarfing (Rht12) and vernalisation response (Vrn1) genes 33 in wheat by using RFLP and microsatellite markers. Plant Breed. 1997, 116, 227-232. [CrossRef]

30. Braun, E.M.; Tsvetkova, N.; Rotter, B.; Siekmann, D.; Schwefel, K.; Krezdorn, N.; Plieske, J.; Winter, P.; Melz, G.; Voylokov, A.; et al. Gene Expression Profiling and Fine Mapping Identifies a Gibberellin 2-Oxidase Gene Co-segregating With the Dominant Dwarfing Gene Ddw1 in Rye (Secale cereale L.). Front. Plant Sci. 2019, 10, 857. [CrossRef]

31. Divashuk, M.G.; Litvinov, D.Y.; Chernook, A.G.; Nazarova, L.A.; Karlov, G.I.; Kroupin, P.Y.; Bazhenov, M.S. Effect of allelic forms of GRFs genes on the development of common wheat under different conditions of nitrogen supplementation. Plant Genet. Genom. Bioinform. Biotechnol. 2021, 10, 53. [CrossRef]

32. Kroupin, P.; Chernook, A.; Karlov, G.; Soloviev, A.; Divashuk, M. Effect of Dwarfing Gene Ddw1 on Height and Agronomic Traits in Spring Triticale in Greenhouse and Field Experiments in a Non-Black Earth Region of Russia. Plants 2019, 8, 131. [CrossRef]

33. Kroupin, P.; Chernook, A.; Karlov, G.I.; Soloviev, A.; Korshunova, A.D.; Divashuk, M.G. Effects of Dwarfing Wheat (Triticum aestivum L.) and rye (Secale cereale L.) genes in spring triticale segregating population asstudied in pot trials. Sel'skokhozyaistvennaya Biol. 2019, 54, 920-933.

34. Kroupin, P.Y.; Karlov, G.I.; Bespalova, L.A.; Salina, E.A.; Chernook, A.G.; Watanabe, N.; Bazhenov, M.S.; Panchenko, V.V.; Nazarova, L.A.; Kovtunenko, V.Y.; et al. Effects of Rht17 in combination with Vrn-B1 and Ppd-D1 alleles on agronomic traits in wheat in black earth and non-black earth regions. BMC Plant Biol. 2020, 20, 304. [CrossRef] [PubMed]

35. Chernook, A.; Kroupin, P.; Karlov, G.; Soloviev, A.; Korshunova, A.; Rubets, V.; Igonin, V.; Divashuk, M. Effects of Rht-B1b and Ddw1 Dwarfing Genes in Two Connecting Populations of Spring Triticale under Greenhouse Experiment Conditions. Agriculture 2019, 9, 119. [CrossRef]

36. Tikhenko, N.; Tsvetkova, N.; Voylokov, A. The Effect of Parental Genotypes of Rye Lines on the Development of Quantitative Traits in Primary Octoploid Triticale: Plant Height. Russ. J. Genet. 2003, 39, 52-56. [CrossRef]

37. Khlestkina, E.; Shvachko, N.; Zavarzin, A.; Börner, A. Vavilov's Series of the "Green Revolution" Genes. Russian J. Genet. 2020, 56, 1371-1380. [CrossRef] 
38. Banaszak, Z. Breeding of Triticale in DANKO. 61 Tagung der Vereinigung der Pflanzenzüchter und Saatgutkaufleute Österreichs; Raumberg-Gumpenstein: Raumberg, Austria, 2010; pp. 65-68.

39. Ittu, G.; Saulescu, N.; Ittu, M.; Mustatea, P. Present and perspectives in Romanian triticale breeding program. Commun Agric Appl. Biol. Sci. 2014, 79, 185-191.

40. Braun, E.M. Erstellung Einer Hochauflösenden Karte für das Dominante Verzwergungsgen Ddw1 im Winterroggen (Secale cereale L.): D.-Technische Universität München. Ph.D. Thesis, Technische Universität München, Munich, Germany, 2021.

41. Zan, T.; Zhang, L.; Xie, T.; Li, L. Genome-Wide Identification and Analysis of the Growth-Regulating Factor (GRF) Gene Family and GRF-Interacting Factor Family in Triticum aestivum L. Biochem Genet. 2020, 58, 705-724. [CrossRef]

42. Sun, L.; Yang, W.; Li, Y.; Shan, Q.; Ye, X.; Wang, D.; Yu, K.; Lu, W.; Xin, P.; Pei, Z.; et al. A wheat dominant dwarfing line with Rht12, which reduces stem cell length and affects gibberellic acid synthesis, is a 5AL terminal deletion line. Plant J. 2019, 97, 887-900. [CrossRef] [PubMed]

43. Buss, W.; Ford, B.A.; Foo, E.; Schnippenkoetter, W.; Borrill, P.; Brooks, B.; Ashton, A.R.; Chandler, P.M.; Spielmeyer, W. Overgrowth mutants determine the causal role of gibberellin GA2oxidaseA13 in Rht12 dwarfism of wheat. J. Exp. Bot. 2020, 71, 7171-7178. [CrossRef] [PubMed]

44. Tang, Y.; Liu, H.; Guo, S.; Wang, B.; Li, Z.; Chong, K.; Xu, Y. OsmiR396d Affects Gibberellin and Brassinosteroid Signaling to Regulate Plant Architecture in Rice. Plant Physiol. 2018, 176, 946-959. [CrossRef]

45. Kalih, R.; Maurer, H.; Miedaner, T. Genetic Architecture of Fusarium Head Blight Resistance in Four Winter Triticale Populations. Phytopathology 2015, 105, 334-341. [CrossRef]

46. Wolski, T.; Gryka, J. Semi-dwarf winter triticale. In Triticale-Today and Tomorrow; Developments in Plant Breeding; Guedes-Pinto, H., Darvey, N., Carnide, V.P., Eds.; Kluwer: Dordrecht, The Netherlands, 1996; Volume 5, pp. 581-587. ISBN 978-94-010-6634-1.

47. Chen, L.; Phillips, A.L.; Condon, A.G.; Parry, M.A.J.; Hu, Y.-G. GA-Responsive Dwarfing Gene Rht12 Affects the Developmental and Agronomic Traits in Common Bread Wheat. PLoS ONE 2013, 8, e62285. [CrossRef] [PubMed]

48. Chen, L.; Hao, L.; Condon, A.G.; Hu, Y.-G. Exogenous GA3 Application Can Compensate the Morphogenetic Effects of the GA-Responsive Dwarfing Gene Rht12 in Bread Wheat. PLoS ONE 2014, 9, e86431. [CrossRef]

49. Chen, L.; Du, Y.; Lu, Q.; Chen, H.; Meng, R.; Cui, C.; Lu, S.; Yang, Y.; Chai, Y.; Li, J.; et al. The Photoperiod-Insensitive Allele Ppd-D1a Promotes Earlier Flowering in Rht12 Dwarf Plants of Bread Wheat. Front. Plant Sci. 2018, 9, 1312. [CrossRef] [PubMed]

50. Worland, A.J.; Sayers, E.J.; Börner, A. The Genetics and Breeding Potential of Rht12, a Dominant Dwarfing Gene in Wheat. Plant Breed. 1994, 113, 187-196. [CrossRef]

51. Komyshev, E.; Genaev, M.; Afonnikov, D. Evaluation of the SeedCounter, A Mobile Application for Grain Phenotyping. Front. Plant Sci. 2017, 7, 1990. [CrossRef]

52. Litvinov, D.Y.; Chernook, A.G.; Kroupin, P.Y.; Bazhenov, M.S.; Karlov, G.I.; Avdeev, S.M.; Divashuk, M.G. A Convenient CoDominant Marker for Height-Reducing Ddw1 Allele Useful for Marker-Assisted Selection. Agriculture 2020, 10, 110. [CrossRef]

53. Fox, J.; Weisberg, S. An R Companion to Applied Regression, 3rd ed.; Sage: Thousand Oaks, CA, USA, 2019; Errata and updates (as of 2020-05-17); Available online: https:/ / socialsciences.mcmaster.ca/jfox/Books/Companion/ (accessed on 17 May 2020).

54. Wickham, H. Ggplot2: Elegant Graphics for Data Analysis; Springer: New York, NY, USA, 2016; ISBN 978-3-319-24277-4. 